\title{
Peran Perempuan dalam Mengembangkan Usaha Mikro Kecil dan Menengah dalam rangka menuju Masyarakat Ekonomi ASEAN di Kota Tangerang Selatan
}

\author{
Fenny Monica A. Hasugian \\ Universitas Kristen Indonesia \\ Lenny Panggabean \\ Universitas Kristen Indonesia
}

\begin{abstract}
Abstrak: Penelitian ini membahas peran yang dilakukan perempuan dalam pengembangan Usaha Mikro Kecil dan Menengah (UMKM) sebagai tujuan berkompetisi pada Masyarakat Ekonomi ASEAN (MEA) di Kota Tangerang Selatan. Metode yang digunakan dalam penelitian ini adalah metode analisis deskriptif dengan cara mendeskripsikan atau menggambarkan data yang telah terkumpul sebagaimana adanya tanpa bermaksud membuat kesimpulan yang berlaku untuk umum atau generalisasi. Metode analisis data yang digunakan adalah Regresi Linear Berganda dengan menggunakan software SPSS. Hasil penelitian menunjukkan peran perempuan dalam peningkatan usaha dan laporan keuangan secara bersama-sama berpengaruh positif dan signifikan terhadap Pengembangan UMKM, secara parsial pengaruh peran perempuan dalam peningkatan usaha berpengaruh positif dan signifikan terhadap pengembangan UMKM, secara parsial laporan keuangan berpengaruh positif dan signifikan terhadap Pengembangan UMKM. Pengaruh peran perempuan dalam peningkatan usaha dan laporan keuangan dapat menjelaskan variasi dari Pengembangan UMKM adalah sebesar $74 \%$ sedangkan sisanya sebesar $26 \%$ dijelaskan oleh variabel-variabel independen yang tidak diteliti.
\end{abstract}

Kata kunci: Perempuan, Ekonomi, Laporan Keuangan, Pengembangan UMKM

Abstract: This study discusses the role of women in the development of Micro Small and Medium Enterprises as a goal of competing in the Asean Economic Community (AEC) in South Tangerang City. The method used in this research is descriptive analysis method describing data that has been collected as it is without intending to make conclusions that are applicable to the public or generalization. Data analysis method used is multiple linear regression using SPSS software. The results showed the role of women in increasing business and financial statements together had a positive and significant effect on the development of MSMEs, partially the influence of the role of women in increasing business had a positive and significant effect on the development of MSMEs, partially the financial statements had a positive and significant effect on the development of MSMEs. The influence of the role of women in improving business and financial statements can explain the variation of MSME Development by $74 \%$ while the remaining $26 \%$ is explained by independent variables not examined.

Key Words: Women, Economy, Finance Report, UMKM Development 
Korespondensi Penulis:

Fenny Monica A. Hasugian, Pusat Studi Wanita, Universitas Kristen Indonesia

Jl. Mayjen Sutoyo No.2, Cawang, Jakarta Timur

E-mail: fenny.monica@uki.ac.id

\section{PENDAHULUAN}

Pelaku usaha perempuan dianggap memiliki potensi untuk menggerakkan ekonomi rakyat dalam menghadapi Masyarakat Ekonomi ASEAN atau disingkat dengan MEA. Mengingat bahwa sebagian besar pelaku usaha di Indonesia, khususnya home industry dan Usaha Mikro Kecil Menengah (UMKM) adalah kaum perempuan. Peran serta perempuan jelas tidak bisa dipandang sebelah mata, ketangguhan perempuan dalam menghadapi krisis pada tahun 1998 merupakan salah satu bukti nyata yang tercatat dalam sejarah perekonomian bangsa.

Di banyak negara berkembang perpindahan perempuan dari sektor pertanian ke sektor industri lebih cepat dari pada laki-laki. Pada tahun 1960 proporsi perempuan yang bekerja ada sektor industri sebesar 21,00 persen dan meningkat menjadi 26,50 persen pada tahun 1980. Pertumbuhannya semakin pesat ketika jumlah industri yang berorientasi ekspor telah diperluas (Bank Dunia 2010). Secara garis besar ada tiga pandangan umum dalam literatur mengenai perempuan dan industrialisasi. Pertama, keterlibatan perempuan dalam industri telah mampu mengangkat derajat perempuan dan kerjanya ke dunia yang lebih kentara, mendobrak struktur pariarkal di dalam rumah dan keluarga, serta memberinya posisi tawar yang lebih baik. Kedua, keterlibatan perempuan dalam industri merupakan suatu hal negatif dan bersifat eksploitatif, karena upah yang rendah tidak adanya perbaikan upah dan kondisi kerja, hubungan dengan lakilaki sering bersifat patriarkal dan sering menjadi sasaran kekerasan seksual. Ketiga, keterlibatan perempuan dalam industri bisa terjadi pada pekerjaan yang sangat eksploitatif tetapi membawa perbaikan posisi sosial dan ekonomi bagi dirinya.

Kecenderungan perempuan lebih menyukai terlibat dalam kegiatan industri rumah tangga dari pada kegiatan industri dalam pabrik. Jam kerja yang lebih luwes dalam industri rumah tangga merupakan keuntungan besar bagi perempuan yang telah berkeluarga, dan khususnya bagi perempuan yang mempunyai anak kecil. Melalui industri rumah tangga mereka masih bisa mengawasi anak-anaknya, namun masalah terpenting yang dihadapi oleh perempuan pekerja industri rumah tangga adalah jam kerja yang tidak teratur dan kebutuhan untuk mendapatkan alat-alat produksi. Berbeda 
dengan perempuan yang bekerja pada industri formal di kota, masalah pengasuhan anak merupakan masalah utama. Bekerja pada industri rumah tangga merupakan pilihan terbaik bagi perempuan yang memiliki anak kecil.

Perempuan dalam kehidupannya memang sudah dibiasakan agar tetap survive dan bekerja untuk menghidupi keluarganya. Meski dengan keterampilan yang masih sangat terbatas dan dalam kondisi yang serba tidak kondusif sekalipun. Seiring dengan gerak zaman, perempuan semakin dimiskinkan. Tenaga kerja perempuan perlahan digeser oleh mesin, tenaga kerja terampil dan pembatasan jenis pekerjaan yang disebabkan oleh nilai-nilai kultural.

Sebuah ironi ditengah kenyataan bahwa perempuan, khususnya perempuan dengan ekonomi rendah adalah tulang punggung keluarga sama halnya seperti laki-laki, meski selalu diposisikan sebagai pencari nafkah tambahan dengan upah yang murah pula.

Perempuan juga menjadi paling rentan terhadap berbagai dampak dari kebijakan ekonomi, tak terkecuali MEA dengan beberapa kebijakannya. Seperti pembangunan pasar tunggal dan liberalisasi pasar tenaga kerja yang pada akhirnya hanya akan memperhadapkan perempuan pada situasi dilematis; antara menjadi pengangguran atau menjadi tenaga kerja murah.

Dengan demikian beban mereka malah akan semakin bertambah. Karena, disamping harus melaksanakan peran domestiknya sebagai ibu dan manajer rumah tangga, mereka pun dituntut memikul peran ganda (double burden) untuk berpikir dan bertanggungjawab terhadap ekonomi keluarga.

Dengan melihat segala potensi yang ada, semestinyalah Indonesia optimis menghadapi MEA. Namun, sekali lagi harus diimbangi dengan upaya untuk menghasilkan produk dan tenaga kerja berkualitas tinggi, di mana masih diperlukan peningkatan sistem pendidikan, pelatihan, standardisasi, sistem manajemen mutu, inovasi, dan teknologi. MEA adalah agenda besar yang harus disambut dan dihadapi bersama. Sehingga baik pemerintah maupun masyarakat, khususnya perempuan harus berbenah. Salah satunya adalah melalui program yang mendorong kemandirian dan kesejahteraan perempuan. Seiring waktu, wacana pemberdayaan dan kemandirian ekonomi perempuan semakin intens ditabuh. Perempuan dan ekonomi, apalagi jika dikaitkan dengan MEA 2015, merupakan sebuah wacana yang dianggap strategis untuk dibahas. Pemerintah pun telah dan sedang mengupayakan berbagai hal yang dianggap penting 
dalam merealisasi dan mengakselerasi kemandirian ekonomi tersebut, diantaranya adalah dengan pemberian bantuan modal.

Paradigma pemberdayaan ekonomi kita mesti dikaji ulang. Salah satunya adalah anggapan bahwa pemberian bantuan modal bisa mengeluarkan perempuan dari kemiskinan tidaklah sepenuhnya benar. Karena sesungguhnya yang demikian hanya mengeluarkan perempuan dari kondisi kemiskinannya. Hal mendesak yang seharusnya dilakukan adalah bagaimana menciptakan lingkungan yang berkeadilan gender, agar perempuan memiliki bargaining position dalam keluarga, masyarakat dan negara. Sehingga mereka bisa mendapatkan akses secara berkeadilan tanpa ada pembatasan berdasarkan kelamin.

Agar perempuan bias lebih sejahtera, bukan hanya dari segi ekonomi tapi juga politik, sosial dan budaya. Kemiskinan harus diretas dengan memahami situasi kemiskinan agar kemandirian ekonomi perempuan tidak lagi sebatas wacana dan perempuan benar-benar bisa menata langkah untuk bersama-sama pemerintah menghadapi MEA.

Berbagai informasi yang telah diperoleh yang menjadi tantangan atau permasalahan UMKM khususnya UMKM berbasis pengusaha perempuan dalam menghadapi MEA tahun 2015 antara lain:

1. Belum adanya kaderisasi secara terstruktur dan berkesinambungan yang mampu menciptakan calon wirausahawan perempuan yang handal

2. Belum maksimalnya dukungan keluarga, karena pada umumnya keluarga beranggapan perempuan mempunyai tanggung jawab yang lebih besar terhadap kebutuhan keluarga sebagai istri dan seorang ibu dari pada sebagai pengusaha.

3. Belum adanya kepastian hukum dari pemerintah daerah terutama dalam perlindungan hukum khususnya bagi UMKM berbasis pengusaha perempuan, untuk kemudahan dalam pengembangan usaha.

4. Belum adanya kebersamaan/sinergi/koordinasi di antara departmen/lembaga terkait, pengembangan UMKM berbasis pengusaha perempuan sehingga masingmasing seakan akan menjalankan program kegiatan masing-masing.

5. Belum adanya kemudahan biaya-biaya yang difasilitasi pemerintah dalam rangka meningkatkan daya saing produk UMKM khususnya UMKM berbasis pengusaha perempuan. 
Berdasarkan latar belakang masalah tersebut maka peneliti tertarik untuk melakukan penelitian dengan judul "Pengaruh peran perempuan dalam peningkatan usaha dan laporan keuangan terhadap Pengembangan UMKM di Kota Tangerang Selatan".

\section{LANDASAN TEORI}

\section{Usaha Mikro Kecil dan Menengah}

\section{Pengertian Usaha Mikro Kecil dan Menengah}

Usaha Mikro Kecil dan Menengah (UMKM) dalam perekonomian Indonesia UMKM merupakan kelompok usaha yang memiliki jumlah paling besar dan terbukti tahan terhadap berbagai macam goncangan krisis ekonomi. Kriteria usaha yang termasuk dalam Usaha Mikro Kecil dan Menengah telah diatur dalam payung hukum. Berdasarkan Undang-Undang Nomor 20 Tahun 2008 tentang Usaha Mikro Kecil dan Menengah (UMKM) ada beberapa kriteria yang dipergunakan untuk mendefinisikan pengertian dan kriteria Usaha Mikro, Kecil dan Menengah.

Menurut Rahmana (2008), beberapa lembaga atau instansi bahkan memberikan definisi tersendiri pada Usaha Kecil Menengah (UKM), diantaranya adalah Kementerian Negara Koperasi dan Usaha Kecil Menengah (Menegkop dan UKM), Badan Pusat Statistik (BPS), Keputusan Menteri Keuangan No 316/KMK.016/1994 tanggal 27 Juni 1994.

Definisi UKM yang disampaikan berbeda-beda antara satu dengan yang lainnya. Menurut Kementerian Menteri Negara Koperasi dan Usaha Kecil Menengah bahwa yang dimaksud dengan Usaha Kecil (UK), termasuk Usaha Mikro (UMI), adalah entitas usaha yang mempunyai memiliki kekayaan bersih paling banyak Rp. 200.000.000,- tidak termasuk tanah dan bangunan tempat usaha, dan memiliki penjualan tahunan paling banyak Rp. 1.000.000.000,-. Sementara itu, Usaha Menengah (UM) merupakan entitas usaha milik warga negara Indonesia yang memiliki kekayaan bersih lebih besar dari Rp. 200.000.000,- s.d. Rp. 10.000.000.000,- tidak termasuk tanah dan bangunan.

\section{Kriteria Usaha Mikro Kecil dan Menengah (UMKM)}

Kriteria Usaha Mikro Kecil Dan Menengah (UMKM) menurut UU Nomor 20 Tahun 2008 digolongkan berdasarkan jumlah aset dan omset yang dimiliki oleh sebuah usaha. Kriteria UMKM tersebut dapat dilihat pada di bawah ini: 
Tabel 1. Kriteria UMKM

\begin{tabular}{|c|l|l|l|}
\hline \multirow{2}{*}{ No } & \multicolumn{1}{|c|}{ Usaha } & \multicolumn{2}{c|}{ Kriteria } \\
\cline { 3 - 4 } & & \multicolumn{1}{c|}{ Aset } & \multicolumn{1}{c|}{ Omset } \\
\hline 1 & Usaha Mikro & Maks. 50 Juta & Maks. 300 Juta \\
\hline 2 & Usaha Kecil & > 50 Juta - 500 Juta & > 300 Juta-2,5 Miliar \\
\hline 3 & Usaha Menengah & > 500 Juta - 10 Miliar & $>2,5$ Miliar - 50 Miliar \\
\hline
\end{tabular}

Sumber : Kementerian Koperasi dan Usaha Kecil dan Menengah, 2012

\section{Kriteria Usaha Kecil dan Menengah berdasarkan Perkembangan}

Berdasar UU UMKM, dari sudut pandang perkembangannya Rahmana (2008) mengelompokkan UMKM dalam beberapa kriteria, yaitu:

1. Livelihood Activities, merupakan usaha kecil menengah yang digunakan sebagai kesempatan kerja untuk mencari nafkah, yang lebih umum dikenal sebagai sektor informal. Contohnya adalah pedagang kaki lima.

2. Micro Enterprise, merupakan usaha kecil menengah yang memiliki sifat pengrajin tetapi belum memiliki sifat kewirausahaan.

3. Small Dynamic Enterprise, merupakan usaha kecil menengah yang telah memiliki jiwa kewirausahaan dan mampu menerima pekerjaan subkontrak dan ekspor

4. Fast Moving Enterprise, merupakan usaha kecil menengah yang telah memiliki jiwa kewirausahaan dan akan melakukan transformasi menjadi Usaha Besar (UB).

\section{Kesetaraan Gender}

Kesetaraan gender merupakan persamaan kondisi dan status antara laki laki dan perempuan sehingga tidak seorang pun yang terabaikan kesempatan dan hak asasinya. Keduanya diberikan kesempatan untuk maju dan berkembang secara sama, tidak ada jenis kelamin yang lebih utama atau diprioritaskan. Kesetaraan gender artinya, laki-laki dan perempuan tidak dibedakan karena jenis kelaminnya, sebaliknya laki-laki dan perempuan diberi kesempatan untuk maju dan berkembang secara sama, tidak ada jenis kelamin yang lebih utama atau diprioritaskan (Hanifah 2013).

\section{Peran Perempuan Dalam Pengelolaan UMKM}

Kontribusi sektor UMKM dalam meningkatkan PDB Indonesia juga tidak luput dari peran perempuan baik sebagai pelaku usaha (pengusaha) maupun sebagai tenaga kerja. 
Meskipun tidak ada data yang pasti tentang UMKM yang dikelola perempuan, tetapi bisa dikatakan bahwa peran perempuan dalam pengembangan sektor UMKM sangat penting. Menurut Priminingtyas (2012) fenomena wanita bekerja untuk mencari nafkah terjadi karena dorongan kebutuhan, kemauan dan kemampuan serta kesempatan kerja yang tersedia dan akses wanita atas kesempatan tersebut. Status ekonomi wanita dilihat dari aktivitasnya dalam kegiatan mencari nafkah, akses terhadap faktor produksi, tingkat pendapatan yang dihasilkan dan kontribusinya terhadap pendapatan keluarga.

Peran perempuan di sektor UMKM umumnya terkait dengan bidang perdagangan dan industri pengolahan seperti: warung makan, toko kecil, pengolahan makanan dan industri kerajinan, karena usaha ini bisa dilakukan di rumah sehingga tidak melupakan peran perempuan sebagai ibu rumah tangga. Meskipun awalnya UMKM yang dilakukan perempuan lebih banyak sebagai pekerjaan sampingan untuk membantu suami dan untuk menambah penadapatan rumah tangga, tetapi bisa menjadi sumber pendapatan rumah tangga utama apabila dikerjakan dengan sungguh-sungguh.

\section{Masyarakat Ekonomi ASEAN (MEA)}

Masyarakat Ekonomi ASEAN (MEA) adalah komunitas ASEAN (ASEAN Community) di bidang Ekonomi atau ASEAN Economic Community (AEC) yang dicanangkan pada Konferensi Tingkat Tinggi (KTT) ASEAN ke-9 di Bali pada tahun 2003, atau dikenal sebagai Bali Concord II. Pembentukan komunitas tersebut diprakarsai oleh para Kepala Negara ASEAN pasca krisis ekonomi tahun 1997 di kawasan Asia Tenggara. Bali Concord II tidak hanya menyepakati pembentukan MEA, namun juga menyepakati pembentukan komunitas ASEAN di bidang Keamanan Politik (ASEAN Political-Security Community) dan Sosial Budaya (ASEAN Socio-Culture Community).

\section{Kerangka Konseptual}

Berdasarkan penjelasan di atas maka pengaruh peran perempuan dalam peningkatan usaha dan laporan keuangan terhadap Pengembangan UMKM di Kota Tangerang Selatan dapat digambarkan dalam kerangka konseptual sebagai berikut: 




Gambar 1 Kerangka Konseptual

\section{Hipotesis Penelitian}

Hipotesis yang diajukan dalam penelitian ini sebagai berikut:

$\mathrm{H}_{1}$ : Peran perempuan dalam peningkatan usaha $\left(\mathrm{X}_{1}\right)$ berpengaruh terhadap Pengembangan UMKM (Y)

$\mathrm{H}_{2}$ : Laporan Keuangan $\left(\mathrm{X}_{2}\right)$ berpengaruh terhadap Pengembangan UMKM (Y)

$\mathrm{H}_{3}$ : Peran perempuan dalam peningkatan usaha $\left(\mathrm{X}_{1}\right)$ dan Laporan keuangan $\left(\mathrm{X}_{2}\right)$ secara bersama-sama berpengaruh terhadap Pengembangan UMKM (Y)

\section{METODE PENELITIAN}

\section{Tempat Penelitian dan Waktu Penelitian}

Tempat penelitian dilakukan di Kota Tangerang Selatan. Waktu penelitian ini dilakukan dari bulan Mei 2018 sampai dengan Oktober 2018.

\section{Populasi dan Sampel}

\section{Populasi}

Menurut Sugiyono (2014) "populasi adalah wilayah generalisasi yang terdiri atas objek/subjek yang mempunyai kualitas dan karakteristik tertentu yang ditetapkan oleh peneliti untuk dipelajari dan kemudian ditarik kesimpulannya".

Populasi dalam penelitian ini adalah seluruh perempuan yang aktif dan memiliki Usaha Mikro Kecil dan Menengah di Kota Tangerang Selatan, untuk jumlah populasi diperoleh dari Dinas Koperasi dan UMKM Kota Tangerang Selatan yang terdaftar sampai bulan Desember 2017 sebanya 350 orang.

\section{Sampel}

Menurut Sugiyono (2014) bahwa sampel merupakan bagian dari jumlah dan karakteristik yang dimiliki oleh populasi tersebut. Bila populasi besar, dan penelitiannya 
tidak mungkin mempelajari semua yang ada pada populasi, misalnya karena keterbatasan dana, tenaga dan waktu maka penelitian dapat menggunakan sampel yang diambil dari populasi itu. Apa yang dipelajari dari sampel itu, kesimpulannya akan dapat diberlakukan untuk populasi.

Hasil perhitungan sampel dengan menggunakan rumus slovin diperoleh sampel sebanyak 78 orang.

\section{Teknik Pengumpulan Data}

Untuk memperoleh data yang lengkap dan teliti, peneliti menggunakan teknik pengumpulan data sebagai berikut:

1. Wawancara (Interview) yaitu mengadakan interview dan tanya jawab secara langsung dengan responden yang terkait dengan objek penelitian.

2. Penyebaran daftar pertanyaan (Questionaire) adalah teknik pengumpulan data yang dilakukan dengan cara mengajukan pertanyaan melalui daftar pertanyaan pada responden terpilih untuk dijawab.

3. Studi dokumentasi dari catatan-catatan yang ada sehubungan dengan data yang diperoleh.

\section{Jenis danSumber Data}

Jenis data yang dikumpulkan untuk mendukung variabel yang diteliti adalah:

1. Data primer

Data Primer adalah data yang diperoleh langsung dari responden penelitian melalui penyebaran kuesioner dan wawancara.

2. Data sekunder

Data Sekunder adalah data yang diperoleh melalui catatan-catatan, laporan, media massa dan dokumen-dokumen lain yang diperoleh.

\section{Definisi Operasional Variabel Penelitian}

Dalam penelitian ini variabel yang digunakan ada 2 yaitu variabel independen dan variabel dependen.

1. Variabel Independen

Menurut Sugiyono (2014) "variabel independen adalah variabel yang mempengaruhi atau yang menjadi sebab perubahannya atau timbulnya variabel 
dependen". Variabel independen yang digunakan dalam penelitian ini adalah peran perempuan dalam mengembangkan UMKM.

2. Variabel Dependen

Menurut Sugiyono (2014) "variabel dependen adalah variabel yang dipengaruhi atau yang menjadi akibat, karena adanya variabel independen". Variabel dependen dalam penelitian ini adalah Kompetisi di MEA.

\section{Uji Asumsi Klasik}

Sebelum model regresi yang diperoleh digunakan untuk menguji hipotesis, terlebih dahulu di uji kualitas data dengan menggunakan asumsi klasik. Uji asumsik lasik yang dilakukan meliputi: uji normalitas, uji multikolinearitas, uji autokorelasi dan uji heteroskedastisitas.

\section{Uji Normalitas}

Menurut Ghozali (2013) "uji normalitas bertujuan untuk menguji apakah dalam model regresi, variable pengganggu atau residual memiliki distribusi normal". Ada dua cara untuk mendeteksi apakah residual berdistribusi normal atau tidak yaitu dengan analisis grafik dan uji statistik.

\section{Analisis Grafik}

Salah satu cara termudah untuk melihat normalitas residual adalah dengan melihat grafik histogram yang membandingkan antara data observasi dengan distribusi yang mendekati distribusi normal. Metode yang lebih andal adalah dengan melihat normal probability plot yang membandingkan distribusi kumulatif dari distribusi normal. Distribusi normal akan membentuk satu garis lurus diagonal, dan ploting data residual normal, maka garis yang menggambarkan data yang sesungguhnya akan mengikuti garis diagonalnya.

Pada prinsipnya normalitas dapat dideteksi dengan melihat penyebaran data (titik) pada sumbu diagonal dari grafik atau dengan melihat histogram dari residualnya. Dasar pengambilan keputusannya adalah:

1. Jika data menyebar disekitar garis diagonal dan mengikuti arah garis diagonal atau grafik histogramnya, menunjukkan pola distribusi normal, maka model regresi memenuhi asumsi normalitas. 
2. Jika data menyebar jauh dari garis diagonal dan/atau tidak mengikuti arah garis diagonal atau grafik histogram tidak menunjukkan pola distribusi normal, maka model regresi tidak memenuhi asumsi normalitas.

\section{Uji Statistik}

Menurut Ghozali (2013) "uji statistik yang dapat digunakan untuk menguji normalitas residual adalah uji statistik non-parametrik Kolmogorov-Smirnov (K-S)”.Uji K-S dilakukan dengan membuathi potesis:

1. $\mathrm{H}_{\mathrm{o}}$ : Data residual berdistribusi normal

2. $\mathrm{H}_{\mathrm{a}}$ : Data residual tidakberdistribusi normal

Bila nilai signifikansi> 0,05 berarti distribusi data normal dan $\mathrm{H}_{\mathrm{o}}$ diterima, sebaliknya bila nilai signifikan< 0.05 berarti distribusi data tidak normal atau $\mathrm{H}_{\mathrm{a}}$ diterima.

\section{Teknik Analisis Data}

\section{Persamaan Regresi}

Analisis data dalam penelitian ini menggunakan analisis regresi linear berganda yang bertujuan untuk mengetahui pengaruh Peran perempuan dalam peningkatan usaha dan laporan keuangan terhadap pengembangan UMKM. Persamaan analisis regresi linear berganda secara umum dalam menguji hipotesis penelitian ini sebagai berikut:

$$
\mathbf{Y}=\mathbf{a}+\mathbf{b}_{1} X_{1}+\mathbf{b}_{2} X_{2}+e
$$

Keterangan:

Y : Pengembangan UMKM

a : Konstanta

$\mathrm{b}_{1} \quad$ : Koefisien regresi

$\mathrm{X}_{1} \quad$ : Laporan keuangan

$\mathrm{X}_{2} \quad$ : Peran perempuan dan peningkatan usaha

e $\quad$ : Persentase kesalahan (5\%)

\section{Koefisien Determinasi}

Menurut Ghozali (2013) "koefisien determinasi ( $\left.\mathrm{R}^{2}\right)$ digunakan untuk mengukur seberapa jauh kemampuan model dalam menerangkan variasi variabel dependen". Nilai koefisien determinasi adalah antara nol dan satu. Nilai $\mathrm{R}^{2}$ yang kecil berarti kemampuan variabel-variabel independen dalam menjelaskan variasi variabel dependen amat terbatas. 
Kelemahan mendasar penggunaan koefisien determinasi adalah bias terhadap jumlah variabel independen yang dimasukkan kedalam model. Setiap tambahan satu variabel independen, maka $\mathrm{R}^{2}$ pasti meningkat tidak peduli apakah variabel tersebut berpengaruh secara signifikan terhadap variabel dependen. Oleh karena itu banyak peneliti menganjurkan untuk menggunakan nilai Adjusted $R^{2}$ pada saat mengevaluasi mana model regresi terbaik. Tidak seperti $\mathrm{R}^{2}$, nilai Adjusted $R^{2}$ dapat naik atau turun apabila satu variabel independen ditambahkan kedalam model.

\section{Pengujian Hipotesis Secara Parsial (Uji-t)}

Menurut Ghozali (2013) "uji parsial digunakan untuk mengetahui pengaruh masingmasing variabel independen terhadap variabel dependen dengan tingkat signifikan 5\%". Kriteria penilaian adalah sebagai berikut:

$\mathrm{H}_{\mathrm{o}}: \mathrm{b}_{1}=0$ (Peran perempuan dalam peningkatan usaha $\left(\mathrm{X}_{1}\right)$ dan Laporan keuangan $\left(\mathrm{X}_{2}\right)$ secara parsial tidak berpengaruh terhadap Pengembangan UMKM).

$\mathrm{H}_{\mathrm{a}}: \mathrm{b}_{1} \neq 0$ (Peran perempuan dalam peningkatan usaha $\left(\mathrm{X}_{1}\right)$ dan Laporan keuangan ( $\left.\mathrm{X}_{2}\right)$ secara parsial tidak berpengaruh terhadap Pengembangan UMKM).

Untuk mengetahui hipotesis yang diajukan diterima atau ditolak dilakukan dengan cara membandingkan thitung dengan tabel pada tingkat kepercayaan 95\% $(\alpha=0.05 \%)$ dengan ketentuan sebagai berikut:

1. Jika nilai $-\mathrm{t}_{\text {tabel }}<\mathrm{t}_{\text {hitung }}<\mathrm{t}$ tabel maka $\mathrm{H}_{\mathrm{o}}$ diterima dan $\mathrm{H}_{\mathrm{a}}$ ditolak.

2. Jika nilai $-t_{\text {hitung }}<-t_{\text {tabelatau }} t_{\text {hitung }}>t_{\text {tabel }}$ maka $\mathrm{H}_{\mathrm{o}}$ ditolak dan $\mathrm{H}_{\mathrm{a}}$ diterima.

\section{Pengujian Hipotesis Secara Simultan (Uji-F)}

Menurut Ghozali (2013) "uji pengaruh simultan digunakan untuk mengetahui apakah variabel independen secara bersama-sama atau simultan mempengaruhi variabel dependen".

Kriteria penilaian adalah sebagai berikut:

$\mathrm{H}_{\mathrm{o}}: \mathrm{b}_{1}, \mathrm{~b}_{2}=0$ (Peran perempuan dalam peningkatan usaha $\left(\mathrm{X}_{1}\right)$ dan Laporan keuangan $\left(\mathrm{X}_{2}\right)$ secara simultan tidak berpengaruh terhadap Pengembangan UMKM).

$\mathrm{H}_{\mathrm{a}}: \mathrm{b}_{1}, \mathrm{~b}_{2} \neq 0$ (Peran perempuan dalam peningkatan usaha $\left(\mathrm{X}_{1}\right)$ dan Laporan keuangan $\left(\mathrm{X}_{2}\right)$ secara simultan berpengaruh terhadap Pengembangan UMKM). 
Untuk mengetahui apakah hipotesis yang diajukan diterima atau ditolak

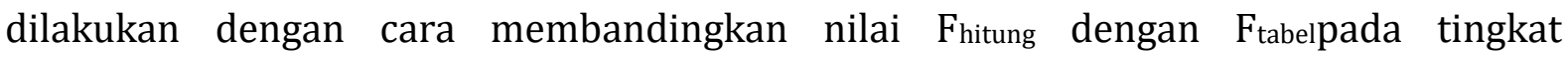
kepercayaan $95 \%(\alpha=0,05)$ dengan ketentuan sebagai berikut:

a. Jika nilai Fhitung $>$ Ftabel, maka $\mathrm{H}_{a}$ diterima dan $\mathrm{H}_{\mathrm{o}}$ ditolak.

b. jika nilai $F_{\text {hitung }}<\mathrm{F}_{\text {tabel }}$ maka $\mathrm{H}_{\mathrm{a}}$ ditolak dan $\mathrm{H}_{\mathrm{o}}$ diterima.

\section{HASIL PENELITIAN DAN PEMBAHASAN}

\section{Hasil Penelitian}

\section{Gambaran Umum Dinas Koperasi dan Usaha Mikro Kecil dan Menengah Kota Tangerang Selatan.}

Dinas Koperasi dan Usaha Mikro Kecil dan Menengah Kota Tangerang Selatan terbentuk berdasarkan Peraturan Walikota Tangerang Selatan Nomor 01 tahun 2009 tentang Organisasi Perangkat Daerah Kota Tangerang Selatan sebagaimana telah diubah dengan Peraturan Walikota Tangerang Selatan Nomor 07 tahun 2009 tentang perubahan atas Peraturan Walikota Tangerang Selatan nomor 01 tahun2009 tentang Organisasi Perangkat Daerah Kota Tangerang Selatan. Pada tahun 2011 kembali dilakukan penyempurnaan melalui terbitnya Peraturan Daerah Nomor 06 tahun 2011 tentang Organisasi Perangkat Daerah Kota Tangerang Selatan, adapun tugas pokok, fungsi dan tata kerja Dinas Koperasi dan Usaha Mikro Kecil Menengah diatur melalui Peraturan Walikota Tangerang Selatan Nomor 14 tahun 2011.

Dinas Koperasi dan Usaha Mikro Kecil dan Menengah merupakan unsur pelaksana otonomi daerah dipimpin oleh seorang Kepala Dinas yang berada dibawah danbertanggung jawab kepada Kepala Daerah melalui Sekretaris Daerah, dalam melaksanakan urusan Koperasi dan Usaha Mikro Kecil dan Menengah. Untuk melaksanakan tugas sebagaimana dimaksud diatas, Dinas Koperasi dan UMKM mempunyai fungsi sebagai berikut:

1. Penyusunan rencana dan program kerja di bidang Koperasi dan Usaha MikroKecil dan Menengah.

2. Pemberian rekomendasi yang berkaitan dengan kegiatan di bidang Koperasi dan Usaha Mikro Kecil dan Menengah. Pelaksanaan kegiatan koordinasi dalam rangka penyusunan program, pengelolaan data dan informasi di bidang perkoperasian dan usaha mikro kecil dan memfasilitasi pembiayaan promosi dan informasi usaha. 
3. Penyusunan, perumusan dan penjabaran kebijakan strategis dan teknis dalam pemberian bimbingan di bidang perkoperasian dan usaha Mikro Kecil dan Menengah serta memfasilitasi pembiayaan promosi dan informasi usaha.

4. Pelaksanaan kebijakan strategis dan teknis dalam pemberian bimbingan dibidang perkoperasian dan usaha Mikro Kecil dan Menengah serta memfasilitasi pembiayaan promosi dan informasi usaha.

5. Pelaksanaan, pengawasan dan pengendalian teknis atas penyelenggaraan bimbingan di bidang perkoperasian dan usaha kecil serta memfasilitasi pembiayaan promosi dan informasi usaha.

6. Pelaksanaan pelayanan fasilitator dengan pihak-pihak instansi pemerintah terkait, BUMN dan swasta dalam rangka peningkatan dan pertumbuhan Koperasi Usaha Mikro Kecil dan Menengah.

7. Pelaksanaan pengelolaan urusan perencanaan dan administrasi kepegawaian serta keuangan.

\section{Analisis Statistik Deskriptif}

Penelitian dilakukan di Kota Tangerang Selatan, variabel bebas (independent variable) yang diamati adalah Pengaruh Peran perempuan dalam peningkatan usaha dan Laporan keuangan sedangkan varibel terikat (dependent variable) adalah Pengembangan UMKM. Berdasarkan hasil analisis deskriptif statistik akan ditampilkan karakteristik sampel yang digunakan didalam penelitian ini meliputi: jumlah sampel $(\mathrm{N})$, rata-rata sampel (mean), nilai maksimum, nilai minimum serta standar deviasi $(\sigma)$ untuk masing-masing variabel. Hasil analisis deskriptif dapat dilihat pada Tabel 2 berikut ini:

Tabel 2. Analisis Deskriptif Penelitian

\begin{tabular}{|c|c|c|c|c|c|}
\hline & N & Min & Max & Mean & Std. Dev \\
\hline X1 & 78 & 3 & 15 & 11.06 & 3.047 \\
\hline X2 & 78 & 5 & 24 & 17.79 & 4.148 \\
\hline Y & 78 & 8 & 38 & 29.12 & 6.491 \\
\hline $\begin{array}{c}\text { Valid N } \\
\text { (listwise) }\end{array}$ & 78 & & & & \\
\hline
\end{tabular}

Sumber: Hasil Penelitian, 2018 (data diolah) 
Berdasarkan hasil output Tabel 2 di atas dapat diketahui variabel pengaruh peran perempuan dalam peningkatan usaha dengan sampel sebanyak 78 responden memiliki rata-rata sebesar 11,06 satuan dengan pengaruh peran perempuan dalam peningkatan usaha minimum sebesar 3 satuan dan maximum15 satuan, serta standar deviasi 3,04 satuan. Hasil analisis dekskriptif menunjukkan bahwa tingkat rata-rata lebih tinggi dari standar deviasi menunjukkan hasil kuesioner rata-rata berdistribusi normal.

Variabel laporan keuangan dengan sampel sebanyak 78 responden memiliki ratarata sebesar 17,79satuan dengan laporan keuangan minimum sebesar 5 satuan dan maximum 24 satuan, serta standar deviasi 4,14 satuan. Hasil analisis dekskriptif menunjukkan bahwa tingkat rata-rata lebih tinggi dari standar deviasi menunjukkan hasil kuesioner rata-rata berdistribusi normal.

Variabel Pengembangan UMKM dengan sampel sebanyak 78 responden memiliki rata-rata sebesar 29,12 satuan dengan kinerja minimum sebesar 8 satuan dan maximum 38 satuan, serta standar deviasi 6,49 satuan. Hasil analisis dekskriptif menunjukkan bahwa tingkat rata-rata lebih tinggi dari standar deviasi menunjukkan hasil kuesioner rata-rata berdistribusi normal.

\section{Pengujian Asumsi Klasik}

Pengujian asumsi klasik digunakan untuk mengetahui model regresi linear berganda dapat digunakan atau tidak. Apabila uji ini terpenuhi maka alat uji dimaksud dapat dipergunakan untuk menguji model yang terdiri dari:

\section{Uji Normalitas}

Uji normalitas dilakukan untuk mengetahui sebuah regresi telah berdistribusi normal atau tidak dapat dilihat pada analisis grafik dan analisis statistik berikut ini:

Pada diagram pencar hasil olah data SPSS dengan dasar pengambilan keputusan yakni jika data menyebar disekitar garis diagonal dan mengikuti arah garis diagonal, maka model regresi memenuhi asumsi normalitas. Hasil pengujian normalitas dapat dilihat pada Gambar 2 di bawah ini: 


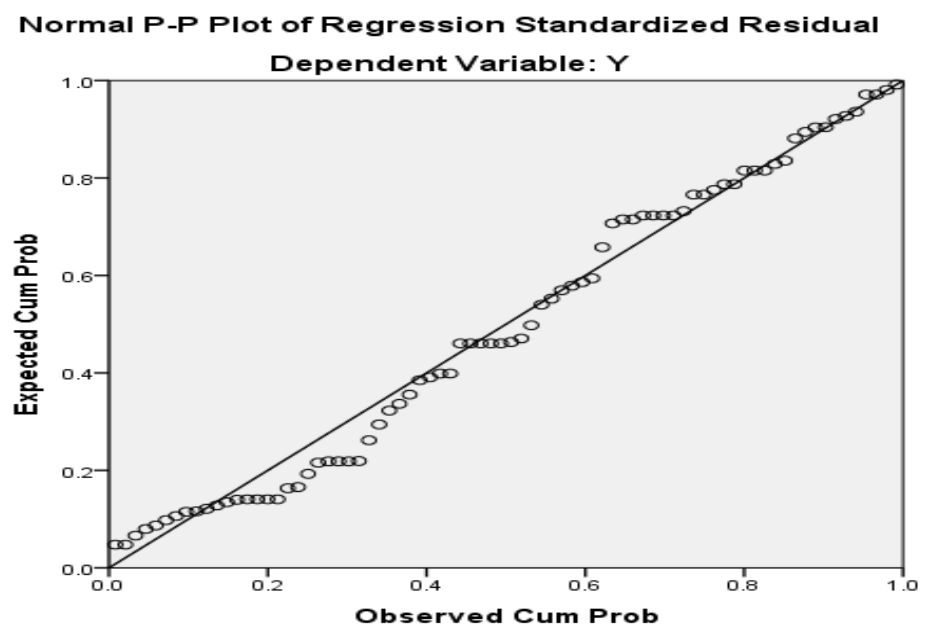

Sumber: Hasil Penelitian, 2018 (data diolah)

Gambar 2 Diagram Pencar Hasil SPSS

Pada Gambar 2 dapat dilihat data menyebar disekitar garis diagonal dan menunjukkan bahwa data berdistribusi normal.

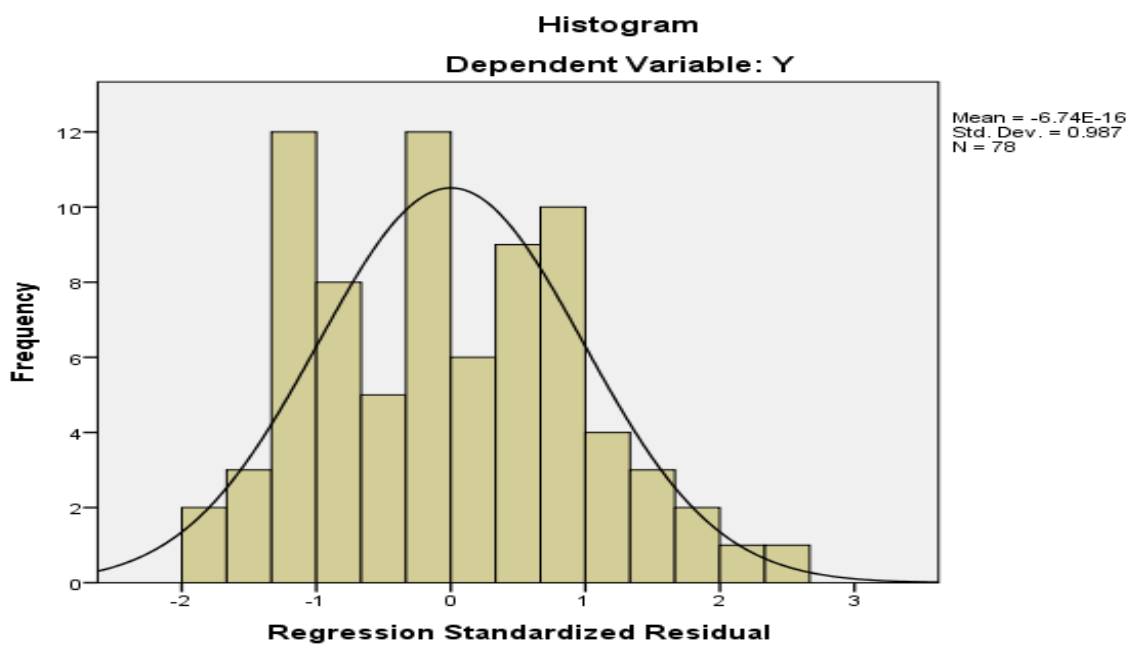

Sumber: Hasil Penelitian, 2018 (data diolah)

Gambar 3. Grafik Histogram

Jika distribusi data residual normal, pola distribusi akan merata di sisi kiri dan sisi kanan. Hasil penelitian menunjukkan bahwa data berdistribusi normal. Hal ini dilihat dari garis diagonal membagi dua sama rata kiri dan kanan.

Uji statistik yang dapat digunakan untuk menguji normalitas residual adalah uji statistik non-parametrik Kolmogorov-Smirnov (K-S). Dimana kriteria pengambilan keputusannya adalah bila signifikansi $>0,05$ berarti distribusi data normal, sebaliknya bila nilai signifikan $<0.05 \%$ berarti distribusi data tidak normal. Hasil uji statistik dapat dilihat pada tabel berikut: 
Tabel 3. One-Sample Kolmogorov-Smirnov Test

\begin{tabular}{|l|l|c|}
\hline \multicolumn{2}{|c|}{} & Unstandardized Residual \\
\hline $\mathrm{N}$ & Mean & 78 \\
\cline { 2 - 3 } $\begin{array}{l}\text { Normal } \\
\text { Parameters }\end{array}$ & Std. Deviation & $0 \mathrm{E}-7$ \\
\hline \multirow{2}{*}{$\begin{array}{l}\text { Most Extreme } \\
\text { Differences }\end{array}$} & Absolute & 3.26438296 \\
\cline { 2 - 3 } & Positive & .104 \\
\cline { 2 - 3 } & Negative & .104 \\
\hline Kolmogorov-Smirnov Z & -.081 \\
\hline Asymp. Sig. (2-tailed) & .922 \\
\hline
\end{tabular}

a. Test distribution is Normal.

b. Calculated from data.

Sumber: Hasil Penelitian, 2018 (data diolah)

Pada Tabel 3 menunjukkan bahwa besarnya nilai Kolmogorov-Smirnov (K-S) adalah 0,922 dan nilai Asymp. Signifikannya adalah 0,363. Jadi dapat disimpulkan bahwa data dalam model regresi telah berdistribusi secara normal karena nilai Asymp sebesar $0,363>0.05$. Sehingga model sudah dapat digunakan untuk menjawab hipotesis penelitian selanjutnya.

\section{Uji Multikolonieritas}

Uji multikolonieritas digunakan untuk mengetahui korelasi antar variabel independent dan ini dapat dilihat dari Variance Inflation Factor (VIF) dengan catatan apabila VIF $>10$ maka diduga mempunyai persoalan multikolinieritas dan apabila VIF $<10$ maka tidak terjadi multikolinieritas. Berdasarkan hasil pengolahan SPSS dilihat pada Tabel 4:

\section{Tabel 4 Hasil Uji Multikolinieritas Coefficientsa}

\begin{tabular}{|ll|c|}
\hline \multirow{2}{*}{ Model } & Collinearity Statistics \\
\cline { 2 - 2 } & (Constant) \\
\hline & X1 & 1.806 \\
X2 & 1.806 \\
\hline
\end{tabular}

a. Dependent Variable: Y

Sumber: Hasil Penelitian, 2018 (data diolah)

Pada Tabel 4 hasil variabel pengaruh Peran perempuan dalam peningkatan usaha dan laporan keuangan nilai VIF lebih kecil dari 10 dan nilai tolerance mendekati 1. Hal ini menunjukkan tidak terjadi gejala multikolinieritas pada variabel yang diuji. 


\section{Uji Heteroskedastisitas}

Uji Heteroskedastisitas bertujuan untuk mengetahui dalam sebuah regressi terjadi kesamaan varians residual, jika varians pengamatan tetap maka disebut homokedasitas, dan jika berbeda disebut heteroskedastisitas, dan model yang baik tentunya tidak terjadi heteroskedastisitas. Dari hasil pengolahan dengan menggunakan SPSS hasil pengolahan data penelitian untuk scatter plot dengan Regression Studentized Residual dapat dilihat pada gambar 4:

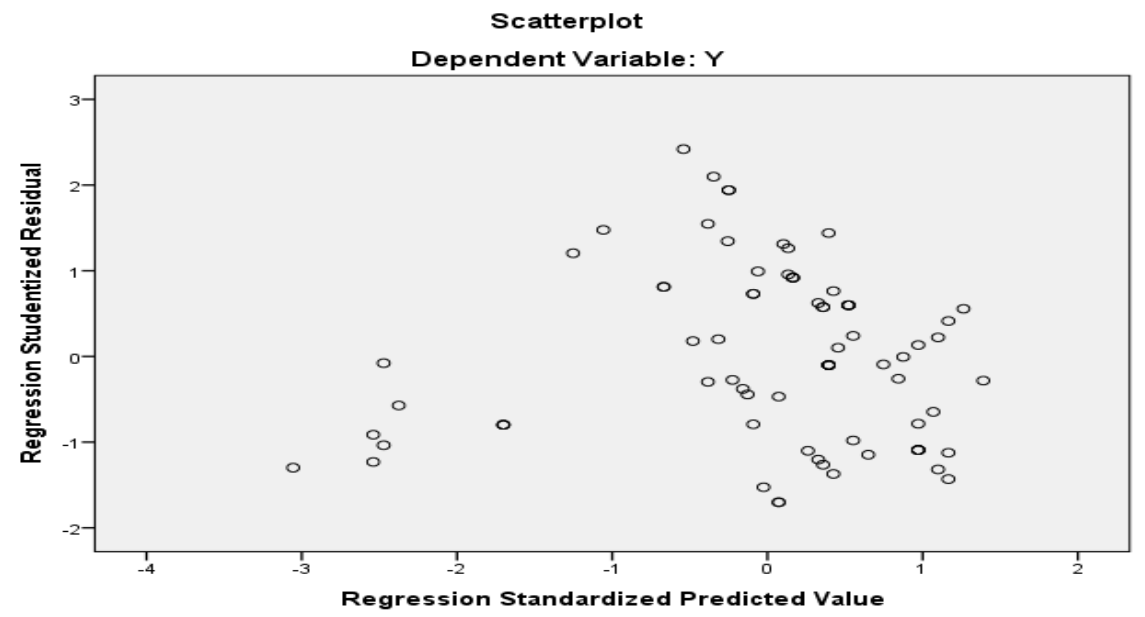

Sumber: Hasil Penelitian, 2018 (data diolah)

\section{Gambar 4 Uji Heteroskedastisitas}

Pada Gambar 4 terlihat titik yang menyebar yang tidak membentuk pola-pola tertentu dan tersebar baik diatas angka 0 pada sumbu Regression Studentized Residual (y) dan berdasarkan gambar tersebut maka tidak terjadi heteroskedastisitas sehingga model regressi layak dipakai untuk memprediksi Pengembangan UMKM berdasarkan variabel independen.

\section{Pengujian Hipotesis}

\section{Uji Parsial/Uji t}

Hasil pengujian hipotesis secara parsial dapat dilihat pada Tabel 5:

Tabel 5 Hasil Uji Hipotesis Secara Parsial/Uji t Coefficients ${ }^{a}$

\begin{tabular}{|l|c|c|c|c|c|}
\hline \multirow{2}{*}{ Model } & \multicolumn{2}{|c|}{ Unstandardized Coefficients } & $\begin{array}{c}\text { Standardized } \\
\text { Coefficients }\end{array}$ & \multirow{2}{*}{$\mathrm{t}$} & \\
\cline { 2 - 4 } & $\mathrm{B}$ & Std. Error & Beta & & \\
\hline \multirow{2}{*}{ (Constant) } & 5.464 & 1.705 & & 3.205 & .002 \\
$\mathrm{X} 1$ & 1.261 & .166 & .592 & 7.582 & .000 \\
$\mathrm{X} 2$ & .545 & .122 & .348 & 4.465 & .000 \\
\hline
\end{tabular}


a. Dependent Variable: $Y$

Sumber: Hasil Penelitian, 2018 (data diolah)

Pada Tabel 5 Hasil uji parsial diperoleh hasil sebagai berikut:

1. Nilai $t$ hitung untuk variabel pengaruh peran perempuan dalam peningkatan usaha sebesar 7,582 lebih besar dibandingkan dengan nilai t tabel $(1,66)$, atau nilai sig $\mathrm{t}$ untuk variabel pengaruh peran perempuan dalam peningkatan usaha $(0,000)$ lebih kecil dari alpha $(0,05)$. Berdasarkan hasil yang diperoleh maka menolak Ho dan menerima $\mathrm{H}_{1}$ untuk variabel pengaruh peran perempuan dalam peningkatan usaha. Dengan demikian, secara parsial pengaruh peran perempuan dalam peningkatan usaha berpengaruh positif dan signifikan terhadap Pengembangan UMKM. Hal ini memberi arti bahwa pengaruh peran perempuan dalam peningkatan usaha berpengaruh nyata dalam meningkatkan pengembangan UMKM. Secara parsial variabel pengaruh peran perempuan dalam peningkatan usaha yang dominan mempengaruhi pengembangan UMKM, maksudnya adalah, variabel pengaruh peran perempuan dalam peningkatan usaha lebih menentukan dalam meningkatkan pengembangan UMKM dibandingkan dengan laporan keuangan.

2. Nilai t hitung untuk variabel laporan keuangan sebesar 4,465 lebih besar dibandingkan dengan nilai t tabel $(1,66)$, atau nilai sig t untuk variabel Laporan keuangan $(0,000)$ lebih kecil dari alpha $(0,05)$. Berdasarkan hasil yang diperoleh maka menolak Hodan menerima $\mathrm{H}_{1}$ untuk variabel laporan keuangan. Dengan demikian, secara parsial laporan keuangan berpengaruh positif dan signifikan terhadap Pengembangan UMKM. Hal ini memberi arti bahwa dengan adanya laporan keuangan memberikan dampak pada peningkatan Pengembangan UMKM. Berdasarkan Tabel 5 maka persamaan regresi linier berganda dalam penelitian ini sebagai berikut:

$$
Y=5,464+1,261 X_{1}+0,545 X_{2}
$$

1. Nilai konstanta regresi sebesar 5,464 artinyabahwapengaruh Peran perempuan dalam peningkatan usaha $\left(\mathrm{X}_{1}\right)$ dan laporan keuangan= 0 maka Pengembangan UMKM bernilai5,464, artinya tanpa adanya dukungan dariPengaruh peran perempuan dalam pengembangan Usaha Miko Kecil dan Menengah dan laporan keuangan maka Pengembangan UMKM dapat meningkat dengan positif. 
2. Koefisien regresi $X_{1}$ untuk variabel pengaruh Peran perempuan dalam peningkatan usaha bernilai positif 1,261artinya bahwa pengaruh variabel pengaruh peran perempuan dalam peningkatan usaha searah dengan peningkatan pengembangan UMKM. Hal ini menunjukkan bahwa variabel pengaruh peran perempuan dalam peningkatan usaha mempunyai pengaruh positif dalam meningkatkan Pengembangan UMKM.

3. Koefisien regresi $\mathrm{X}_{2}$ untuk variabel laporan keuangan bernilai positif 0,545 artinya bahwa pengaruh variabel laporan keuangan searah dengan peningkatan pengembangan UMKM. Hal ini menunjukkan bahwa variabel laporan keuangan mempunyai pengaruh positif dalam meningkatkan pengembangan UMKM.

\section{Uji Simultan/Uji F}

Uji simultan/uji F dilakukan untuk mengetahui tingkat positif dan signifikansi dari variabel pengaruh peran perempuan dalam peningkatan usaha dan laporan keuangan terhadap variabel Ppngembangan UMKM dapat dilihat pada Tabel 6:

Tabel 6 Hasil Pengujian Hipotesis secara Simultan/Uji F ANOVAa

\begin{tabular}{|l|c|c|c|c|c|}
\hline Model & Sum of Squares & df & Mean Square & F & Sig. \\
\hline Regression & 2423.434 & 2 & 1211.717 & 110.757 & $.000^{\mathrm{b}}$ \\
1 Residual & 820.527 & 75 & 10.940 & & \\
Total & 3243.962 & 77 & & & \\
\hline
\end{tabular}

a. Dependent Variable: $Y$

b. Predictors: (Constant), X2, X1

Sumber: Hasil Penelitian, 2018 (data diolah)

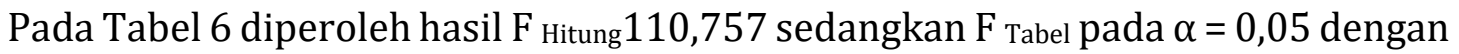
ketentuan df2=k-1 = 3-1 maka derajat pembilang 2 dan derajat penyebut, df2=772=75maka diperoleh $\mathrm{F}$ tabel3,15 dari hasil ini diketahui $\mathrm{F}$ hitung $>\mathrm{F}$ tabel, dan signifikansi 0,000 atau lebih kecil dari $\alpha=0,05$ jadi posisi titik uji signifikansi berada pada wilayah penolakan $\mathrm{H}_{0}$ atau dapat disimpulkan $\mathrm{H}_{1}$ diterima yang artinya bahwa variabel pengaruh peran perempuan dalam peningkatan usaha dan laporan keuangan secara bersamasama berpengaruh positif dan signifikan terhadap pengembangan UMKM, artinya bahwa dengan adanya pengaruh peran perempuan dalam peningkatan usaha dan laporan keuangan memberikan dampak positif bagi perempuan sebagai pelaku UMKM untuk meningkatkan pengembangan UMKM. 


\section{Koefisien Determinasi $\left(\mathbf{R}^{2}\right)$}

Koefisien determinasi merupakan besaran yang menunjukkan besarnya variasi variabel dependen (pengembangan UMKM) yang dapat dijelaskan oleh variabel independen (pengaruh peran perempuan dalam peningkatan usaha dan Laporan keuangan). Nilai koefisien determinasi ditentukan dengan nilai $R$ square, dapat dilihat pada tabel 7:

Tabel 7 Model Summaryb

\begin{tabular}{|c|c|c|c|c|}
\hline Model & $\mathrm{R}$ & R Square & Adjusted R Square & Std. Error of the Estimate \\
\hline 1 & $.864^{\mathrm{a}}$ & .747 & .740 & 3.308 \\
\hline
\end{tabular}

a. Predictors: (Constant), X2, X1

b. Dependent Variable: Y

Sumber: Hasil Penelitian, 2018 (data diolah)

Berdasarkan Tabel 7 di atas nilai adjusted $R$ Square adalah 0,740 artinya bahwa kemampuan variabel pengaruh peran perempuan dalam peningkatan usaha dan laporan keuangan dapat menjelaskan variasi dari pengembangan UMKM adalah sebesar 74\% sedangkan sisanya sebesar 26\% dijelaskan oleh variabel-variabel independen yang tidak diteliti, artinya bahwa kemampuan variabel pengaruh peran perempuan dalam peningkatan usaha dan laporan keuangan dalam menjelaskan variasi atau pengaruh terhadap pengembangan UMKM adalah cukup kuat, karena nilai R Square sebesar 74\% diatas standar 50\%,

\section{PEMBAHASAN}

\section{Pengaruh Pengaruh Peran perempuan dalam peningkatan usaha dan Laporan keuangan terhadap Pengembangan UMKM}

Hasil penelitian yang dilakukan peneliti membuktikan bahwa secara simultan adanya pengaruh antara peran perempuan dalam peningkatan usaha terhadap pengembangan UMKM. Hal tersebut dapat dilihat dari uji simultan menolak $\mathrm{H}_{0}$ sedangkan menerima $\mathrm{H}_{1}$ yang menunjukkan pengaruh peran perempuan dalam peningkatan usaha dan Laporan keuangan berpengaruh positif dan signifikan terhadap pengembangan UMKM. Dengan 
demikian dapat disimpulkan bahwa variabel pengaruh peran perempuan dalam peningkatan usaha dan laporan keuangan dapat meningkatkan pengembangan UMKM.

\section{Pengaruh Peran Perempuan dalam Peningkatan Usaha terhadap Pengembangan UMKM}

Hasil penelitian yang dilakukan peneliti membuktikan bahwa adanya pengaruh antara pengaruh peran perempuan dalam peningkatan usaha terhadap pengembangan UMKM. Hal tersebut dapat dilihat dari uji parsial menolak $\mathrm{H}_{0}$ dan menerima $\mathrm{H}_{1}$ yang menunjukkan pengaruh peran perempuan dalam peningkatan usaha berpengaruh positif dan signifikan terhadap Pengembangan UMKM. Dengan demikian dapat disimpulkan bahwa variabel pengaruh peran perempuan dalam peningkatan usaha mempengaruhi pengembangan UMKM. Permodalan merupakan faktor utama yang diperlukan untuk mengembangkan suatu unit usaha. Kurangnya permodalan UMKM, oleh karena pada umumnya usaha Mikro Kecil dan Menengah merupakan usaha perorangan atau perusahaan yang sifatnya tertutup,yang mengandalkan pada modal dari si pemilik yang jumlahnya sangat terbatas, sedangkan modal pinjaman dari bank atau lembaga keuangan lainnya sulit diperoleh, karena persyaratan secara administratif dan teknis yang diminta oleh bank tidak dapat dipenuhi

\section{Pengaruh Laporan Keuangan terhadap Pengembangan UMKM}

Hasil penelitian yang dilakukan peneliti membuktikan bahwa adanya pengaruh antara laporan keuangan terhadap pengembangan UMKM. Hal tersebut dapat dilihat dari uji parsial menolak $\mathrm{H}_{0}$ dan menerima $\mathrm{H}_{1}$ yang menunjukkan laporan keuangan berpengaruh positif dan signifikan terhadap pengembangan UMKM. Dengan demikian dapat disimpulkan bahwa variabel laporan keuangan mempengaruhi pengembangan UMKM.

Usaha kecil yang pada umumnya merupakan unit usaha keluarga,mempunyai jaringan usaha yang sangat terbatas dan kemampuan penetrasi pasar yang rendah, oleh karena produk yang dihasilkan jumlahnya sangat terbatas dan mempunyai kualitas yang kurang kompetitif. Berbeda dengan usaha besar yang telah mempunyai jaringan yang sudah solid serta didukung dengan teknologi yang dapat menjangkau internasional dan promosi yang baik. 


\section{KESIMPULAN}

Berdasarkan hasil penelitian dan pembahasan yang telah diuraikan pada bab sebelumnya, maka dapat ditarik kesimpulan sebagai berikut:

1. Hasil dari $\mathrm{F}$ Hitung 110,757 sdangkan nilai diperoleh $\mathrm{F}$ tabel 3,15 dari hasil ini diketahui $F$ hitung $>F$ tabel, dan signifikansi 0,000 atau lebih kecil dari $\alpha=0,05$ jadi posisi titik uji signifikansi berada pada wilayah penolakan $\mathrm{H}_{0}$ atau dapat disimpulkan $\mathrm{H}_{1}$ diterima yang artinya bahwa variabel pengaruh peran perempuan dalam peningkatan usaha dan laporan keuangan secara bersama-sama berpengaruh positif dan signifikan terhadap pengembangan UMKM, artinya bahwa dengan adanya pengaruh peran perempuan dalam peningkatan usaha dan laporan keuangan memberikan dampak positif bagi perempuan sebagai pelaku UMKM untuk meningkatkan pengembangan UMKM.

2. Nilai t hitung untuk variabel pengaruh peran perempuan dalam peningkatan usaha sebesar 7,582 lebih besar dibandingkan dengan nilai t tabel $(1,66)$, atau nilai sig t untuk variabel pengaruh peran perempuan dalam peningkatan usaha $(0,000)$ lebih kecil dari alpha $(0,05)$. Berdasarkan hasil yang diperoleh maka menolak Ho dan menerima $\mathrm{H}_{1}$ untuk variabel pengaruh peran perempuan dalam peningkatan usaha. Dengan demikian, secara parsial pengaruh peran perempuan dalam peningkatan usaha berpengaruh positif dan signifikan terhadap pengembangan UMKM. Hal ini memberi arti bahwa pengaruh peran perempuan dalam peningkatan usaha berpengaruh nyata dalam meningkatkan pengembangan UMKM.

3. Nilai t hitung untuk variabel laporan keuangan sebesar 4,465 lebih besar dibandingkan dengan nilai t tabel $(1,66)$, atau nilai sig t untuk variabel laporan keuangan $(0,000)$ lebih kecil dari alpha $(0,05)$. Berdasarkan hasil yang diperoleh maka menolak $\mathrm{H}_{0}$ dan menerima $\mathrm{H}_{1}$ untuk variabel laporan keuangan. Dengan demikian, secara parsial laporan keuangan berpengaruh positif dan signifikan terhadap pengembangan UMKM. Hal ini memberi arti bahwa dengan adanya laporan keuangan memberikan dampak pada peningkatan pengembangan UMKM.

4. Nilai adjusted $R$ Square adalah 0,740 artinya bahwa kemampuan variabel pengaruh peran perempuan dalam peningkatan usaha dan laporan keuangan dapat menjelaskan variasi dari pengembangan UMKM adalah sebesar 74\% sedangkan sisanya sebesar $26 \%$ dijelaskan oleh variabel-variabel independen 
yang tidak diteliti, artinya bahwa kemampuan variabel pengaruh peran perempuan dalam peningkatan usaha dan Laporan keuangan dalam menjelaskan variasi atau pengaruh terhadap pengembangan UMKM adalah cukup kuat.

\section{REFERENSI}

Badan Pusat Statistik. 2013. "Klasifikasi Baku Lapangan Usaha Indonesia Revisi KBLI" Jakarta: BPS.

Berita Padang Media. 2016. "Kekerasan Terhadap Perempuan Masih Tinggi" terbit 8 Maret 2016 diakses dari http://padangmedia.com/kekerasan-terhadapperempuan-masih-tinggi/

Dianingtyas, Murtanti, Putri. 2016. "Peran Perempuan dalam Pembentukan SDM (Sumber Daya Manusia) yang Berkualitas menghadapi MEA (Masyarakat Ekonomi Asean), Program Studi Ilmu Komunikasi Fakultas Ekonomi dan Ilmu Sosial. Prosiding Seminar Nasional Indocompac Universitas Bakrie.

Dipta, I Wayan. 2009. "Mengangkat Peran Perempuan Pengusaha dalam mengatasi Pengangguran". Jakarta: Kementerian Negara Koperasi dan UKM.

Ghozali, Imam. 2013. "Aplikasi Analisis Multivariate dengan Program SPSS”. Cetakan Keempat. Semarang: Badan Penerbit Universitas Diponegoro.

Hanifah, Laily. 2013. “Keadilan dan Kesetaraan Jender (Perspektif Islam)”. Jakarta: Tim Pemberdayaan Perempuan Bidang Agama Departemen Agama RI

Harian Umum Kompas. 2003. "Jender”.

Hill,C.W.L., Jones, G.R. 2010. Strategic Management: An Integrated Approach:Theory. Mason: Cengage Learning.

Ikatan Akuntan Indonesia. 2010. "Pernyataan Standar Akuntansi Keuangan”, No.2 Laporan Arus Kas (Revisi 2009), Jakarta: Salemba Empat.

Kadarningsih, Ana. 2013. "Keunggulan Bersaing; Faktor-Faktor yang mempengaruhi dan dampaknya pada Kinerja Selling-In (Studi pada Outlet Binaan PT. Indosat Semarang). Jurnal Media Ekonomi \& Teknologi Informasi Vol. 21 No. 1 Maret, 01 18

Momsen, Janet Henshall. 2012. Gender and Development. London and New York: Routledge

Nenny. 2008. "Industri Kreatif”. Jurnal Ekonomi, Desember 2008 Volume XIII No. 3.

Priminingtyas, Dina Novia. 2012. "Akses Usaha Kecil Menengah (UKM) dalam mendapatkan Kredit Usaha dari Lembaga Perbankan di Kota Malang. Prosiding Seminar Internasional The Future of Small Businesses from Accounting, Management an dEconomics Perspectives Fakultas Ekonomi Universitas Jenderal Soedirman Purwokerto.

Priminingtyas, Dina Novia. 2013. "Peran Perempuan dalam Pengembangan Sektor Usaha Mikro Kecil Menengah (UMKM)" Jurnal Jurusan Sosial Ekonomi Pertanian, Fakultas Pertanian Universitas Brawijaya Malang. 
Sugiyono. 2014. "Metode Penelitian Bisnis”. Cetakan Keenam. Bandung: Alfabeta.

Tim Rifka Annisa. 2013. "Ketidakadilan Jender, Kesetaraan Jender, dan Pengarusutamaan"

Zimmerer, T. W., Scarborough, N. M., Wilson, D. 2008. "Kewirausahaan dan Manajemen Usaha Kecil". Jakarta: Salemba Empat. 